\title{
Macrocospic and physiochemical characterization of a sugarless and gluten-free cake enriched with fibers made from pumpkin seed (Cucurbita maxima, L.) flour and cornstarch
}

\author{
Caracterização macroscópica e físico-química de bolo isento de açúcar, com fibra e sem glúten \\ a base de farinha mista de semente de abóbora (Cucurbita maxima, L.) e amido de milho
}

\section{Cristiane Mesquita da Silva GORGÔNIO ${ }^{1 *}$, Matilde PUMAR ${ }^{1}$, Cheila Gonçalves MOTHÉ2}

\begin{abstract}
The Consumers' interest for products with caloric reduction has increased, and their development is a technological challenge. The consumption of cakes has grown in importance and the demand for dietary products has stimulated the use of sweeteners and the optimization of bakery products. The consumption of fibers is related to chronic diseases prevention. Pumpkin seeds (maximum Cucurbita, L.), rich in fibers, can be used as a source of fiber in food products. A gluten-free diet is not easy to follow since gluten free products are not always available. The objective of this work was to perform a physicochemical characterization of cakes prepared with flours blends (FB) based on Pumpkin Seed Flour (PSF). The cakes were elaborated with FB in the ratios of 30:70 (C30) and 40:60 (C40) of PSF and cornstarch (CS), respectively. The results showed gluten absence and near-neutral $\mathrm{pH}$. The chemical analysis of $\mathrm{C} 30$ and $\mathrm{B} 40$ showed increase of ashes, lipids, proteins, and insoluble dietary fiber and a decrease in the content of carbohydrates and calories. The chemical composition of C40 presented the greatest content of lipids, proteins, and dietary fibers, the lowest content of calories, and the best physical parameters. Therefore, both products proved suitable for human consumption.
\end{abstract}

Keywords: pumpkin seed flour; cake; fiber; dietary; gluten.

\section{Resumo}

O interesse do consumidor por produtos com redução calórica é crescente e seu desenvolvimento um desafio tecnológico. O produto bolo vem adquirindo crescente importância de consumo e a demanda por produtos dietéticos vem estimulando a utilização de edulcorantes e a otimização de produtos panificados. O consumo de fibra alimentar associa-se à prevenção de doenças crônicas, e a semente da abóbora (Cucurbita maxima, L.), rica em fibra alimentar, pode ser utilizada como fonte, em produtos alimentícios. Uma dieta isenta de glúten não constitui prática fácil, sendo raros os produtos panificados deste tipo. O objetivo deste trabalho é caracterizar de forma físico-química bolos elaborados com Farinhas Mistas (FM) à base de Farinha de Semente de Abóbora (FSA). Os bolos foram elaborados com FM nas proporções 30:70 (B30) e 40:60 (B40) a partir de FSA e Amido de Milho (AM), nesta ordem. Os resultados mostraram ausência de glúten e pH próximo à neutralidade. As análises químicas de B30 e B40 mostraram aumento no teor de cinzas, lipídios, proteínas e fibra alimentar insolúvel e, por outro lado, diminuição no teor de carboidratos e calorias. A composição química do B40 apresentou os melhores parâmetros físicos, e a composição química mostrou maior teor de lipídios e fibra alimentar e menor de calorias.

Palavras-chave: farinha de semente de abóbora; bolo; fibra; dietético; glúten.

\section{Introduction}

There has been an increase in the worldwide interest in improving the quality of nutrition and reducing health care costs through the prevention of chronic diseases and extended life expectancy (STRINGHETA et al., 2007). The Non-Transmissible Chronic Diseases (NTCDs) are associated to the most common causes of death including obesity, diabetes, high blood pressure, stroke (cerebrovascular accident (CVA)), osteoporosis, cancer, and coronary diseases (BRASIL, 2005; FERREIRA; LANFERMARQUEZ, 2007).
Gluten, present in wheat, is responsible for the texture of bakery products and is a composite of the proteins gliadin and glutenin. Celiac Disease (CD) expresses gliadin sensitivity. It is one of the most common causes of chronic diarrhea in children resulting in poor intestinal absorption of vitamins. The only possible and efficient treatment is a life-long gluten-free diet avoiding the consumption of gliadin (HADJIVASSILOU et al., 1996; SDEPANIAN; MORAIS; FAGUNDES-NETO, 1999; MAHAN; ESCOTT-STUMP, 2002; ORNELLAS, 2002;

Recebido para publicação em 24/11/2008

Aceito para publicação em 14/2/2010 (003963)

${ }^{1}$ Laboratório de Tecnologia dos Alimentos, Departamento de Nutrição Básica e Experimental, Instituto de Nutrição, Bloco D, Universidade do Estado do Rio de Janeiro - UERJ, Rua São Francisco Xavier, 524, $12^{\circ}$ andar, Maracanã, CEP 20550-013, Rio de Janeiro - RJ, Brasil, E-mails: tianemsilva@yahoo.com.br; pumar.m@ig.com.br

2 Departamento de Processos Orgânicos, Escola de Química, Universidade Federal do Rio de Janeiro - UFRJ, Av. Horácio Macedo, 2030, Ed. do Centro de Tecnologia, bl. E, sala 204, CEP 21941-909, Cidade Universitária, Rio de Janeiro - RJ, Brasil

${ }^{*}$ A quem a correspondencia deve ser enviada 
CAFÉ et al., 2003; GALVÃO et al., 2004; RAUEN; BACK; MOREIRA, 2005; ANJUM et al., 2007).

Recently, the search for vegetables that can be used whole in order to minimize losses and increase the foods' nutrient content has increased. This includes the use of leaves, stalk, and seeds which are commonly discarded in traditional cuisine although they are actually by-products that can be used in the industry due to their rich nutritional composition (DIGA..., 1992; ESTEVES et al., 1993; DOURADO et al., 2000; TURANO et al., 2000).

Pumpkin seeds (PS), which used to be discarded after the pre-processing of the fruit, have been, nowadays, subjected to industrial processing and have been commonly commercialized as a savory appetizer. The application of these seeds can be considered a good alternative for the nutritional enrichment of food products. Pumpkin seeds are rich in iron and therefore can be used in regions which lack this mineral. They are rich in fats (40 to $60 \%)$ and proteins (25.2 to $40 \%$ ) and have low contents of free sugars and starch. The majority of the oils present in PSs are unsaturated such as the oleic (C18:1) and the linoleic oil (C18:2), which account for 26.3 and $52.4 \%$ of the seeds composition, respectively. The unsaturated fatty acid, linoleic, produces beneficial effects on the human body, immune system, cardiovascular diseases, diabetes, and cancer (YOUNIS; GHIRMAYB; AL-SHIHRYC, 2000; EL-ADAWY; TAHA, 2001a,b; MURKOVIC et al., 2004; FUNCK; BERRERRAARELLANO; BLOCK, 2006; KALLUF, 2006).

Some authors studied the anthelmintic and toxic effects of pumpkin seeds. Del-vechio et al. (2005) investigated the toxicological characteristics of the pumpkin seed (C. maxima) flour (PSF) made from seeds treated differently: raw, cooked by boiling at the ratio of 1:10 for 10 minutes, and roasted at $100{ }^{\circ} \mathrm{C}$ for 90 minutes. These authors found that the PSF made from raw, cooked, and roasted seeds presented 7, 4.4, and $5.52 \mathrm{mg} .100 \mathrm{~g}^{-1}$ of cyanide, respectively. According to them, the lethal dose of cyanide varies within 0.5 and $3.5 \mathrm{mg} . \mathrm{kg}^{-1}$ of body weight and the recommended maximum intake (or safe limits) of PSF is $250 \mathrm{~g}$. Nevertheless, it is necessary to study its cumulative effects on the body.

On the other hand Dallemole-Giaretta et al. (2009) found that the aqueous extract of the pumpkin seed flour have effects on the hatching of nematode eggs and inactivation of this parasite, which causes deterioration and spoilage of root vegetables.

The dietary fiber (DF) is an edible plant material, not hydrolyzed by the endogenous enzymes of the human digestive tract, which aids constipation treatments. Its physiological effect depends on the kind of fiber (soluble or insoluble). Constipation can be caused by poor hydric ingestion, but its major cause is insufficient consumption of fibers. In addition, the ingestion of dietary fibers, mainly insoluble fibers, can decrease the risk for obesity, type II diabetes (DMNID), and cardiovascular diseases (BRASIL, 2003, 2005; POSSAMAI, 2005;
BORGES et al., 2006; CERQUEIRA, 2006; SANTANGELO, 2006; STRINGHETA et al., 2007).

Pumar et al. (2008) studied the physiological effects of the whole, sifted and residual pumpkin seed flour fibers on rats and found that the group treated with PSF presented more compact fecal matter and increased volume of feces. The feces expelled were associated to the higher content of insoluble fiber, which indicated the physical influence of the dietary fiber present in PSF, especially residual PSF.

Flour quality can be defined based on its product's sensory characteristics such as taste and odor, as well as high nutritional value and low cost. The absorption capacity of the all purpose flour varies between 55 e 65\% (POSSAMAI, 2005). Loss of nutrients can occur during flour processing, and therefore it is necessary to join the properties of previously processed flour to the optimum nutritional characteristics of wheat flours such as PSF. The use of PSF in animal feed, sweets, and biscuits among other products has been investigated to determine whether flour blends have chemical, physical, and functional characteristics that can result in high quality commercial products (PEREIRA et al., 2009; PUMAR et al., 2008; BERETTA, 2007).

Diet and light brands of food products account for only $5 \%$ of the Brazilian food and beverage market, but the use a wide variety of low calorie and sugarless products has been increasing. Diet food products are intended for people with diabetes, but they can be consumed by everyone else. The use of sweeteners to replace sugar in conventional formulations is complex, and some sweeteners affect food products' stability. In order to achieve the appearance and texture found in conventional food products, some industries increase the content of other components such as fat, which results in a product as high in calories as conventional products (CARDELLO; DAMÁSIO, 1997; CAMPOS, 2007).

Cake consumption and commercialization have been growing in importance in Brazil mainly due to the technical development that has allowed small-scale industries become large-scale industries such as those that produce the "ready to eat cake" and cake mix. (MOSCATTO; PRUDÊNCIO-FERREIRA; HAULY, 2004; PAVANELLI; CICHELLO; PALMA, 2005).

Therefore, the objective of the present work was to prepare gluten-free, diet English cakes enriched with fibers using PSF and cornstarch as ingredients to study the macroscopic and chemical characteristics of such formulations.

\section{Materials and methods}

\subsection{Materials}

\section{Flour made from pumpkin seed and cornstarch}

The "in natura" seeds of the pumpkin (Cucurbinata maxima, L.) seed flour were washed and spread evenly on aluminum trays. The seeds were then subjected to dehydration 
in a Fanen forced ventilation drying and sterilization oven (Model 330) at isothermal temperature of $70{ }^{\circ} \mathrm{C}$ for 13 hours. Next, the seeds were dried and ground using a regular 2-liter blender (Performa Magiclean Chrome Arno) for 50 seconds by pressing and holding the pulse buttom every 10 seconds (BERETTA et al., 2007; CARESTIATO et al., 2005). The powder was sifted and the residue was subjected to fractionation using an analytical mill (JK A10 ), at $20000 \mathrm{rpm}$, for 1 minute. The material was then sifted once more (BERETTA et al., 2007; CARESTIATO et al., 2005).

\section{Cake formulations}

In order to begin the preparation of the experimental cakes, a cake was prepared using simple flour blend (FB), based on wheat flour and cornstarch, and it was considered the Standard Cake (SC).

The ingredients of the SC were flour blend, refined sugar, whole milk, eggs, margarine, yeast powder, and salt.

The SC formulation was used as a parameter for the development of the formulations of the experimental cakes. At the beginning of the study two cakes were prepared. One was prepared using flour blend (FB) made from cornstarch and PSF (30:70), and the other was prepared with wheat flour and PSF (30:70). Both cakes presented similar sensory characteristics. Nonetheless, the gluten-free cake prepared using the blend flour made from PSF and cornstarch was used in the rest of the experimental study.

Cakes were prepared with different mixing ratios of 30:70, 50:50, and 70:30 of PSF and cornstarch, respectively. The yields of these cake formulations were $85.6,89.8$, and $89.3 \%$, respectively, indicating that the yield increased with the increase in the PSF content. The following dimensions of the cakes were measured: length, height, and width $(\mathrm{cm})$.

Despite the good yield and different dimensions, the cakes with 70 and $50 \%$ of PSF presented some characteristics that affected their appearance, such as dark color, and the texture of the batter. Hence, the formulations containing 30 and $40 \%$ of PSF were chosen to be investigated in this study.

It was necessary to adapt the baking temperature according to the different experimental cakes used. In preliminary studies, it was verified that temperatures higher than $165^{\circ} \mathrm{C}$ cooked the outside of the cake but not the inside. Reducing the baking temperature to $150^{\circ} \mathrm{C}$, resulted in a more evenly baked cake.

Nevertheless, reducing the temperature revealed the need to increase the experimental cakes' baking times. Specific baking time and temperatures were set for the preparation of each experimental cake, as described in Figure 1.

The concentration of the flour blends made from PSF and cornstarch used were 30 and 40\%, FB30 and FB40, respectively, The FB30 and FB40 were used to prepare C30 and C40. The ingredients used in these two formulations were Tal \& Qual, artificial sweetener, skim milk, eggs, margarine, yeast powder, salt, and an emulsifier $\left(\mathrm{Mix}^{\circledast}\right)$. Table 1 shows these formulations.

\subsection{Methods}

\section{Cakes'preparation}

The ingredients were weighed. The eggs yolk, margarine, and sugar, in the case of SC, or the artificial sweetener, in the

Table 1. Ingredients of standard cake (SC) and experimental cakes.

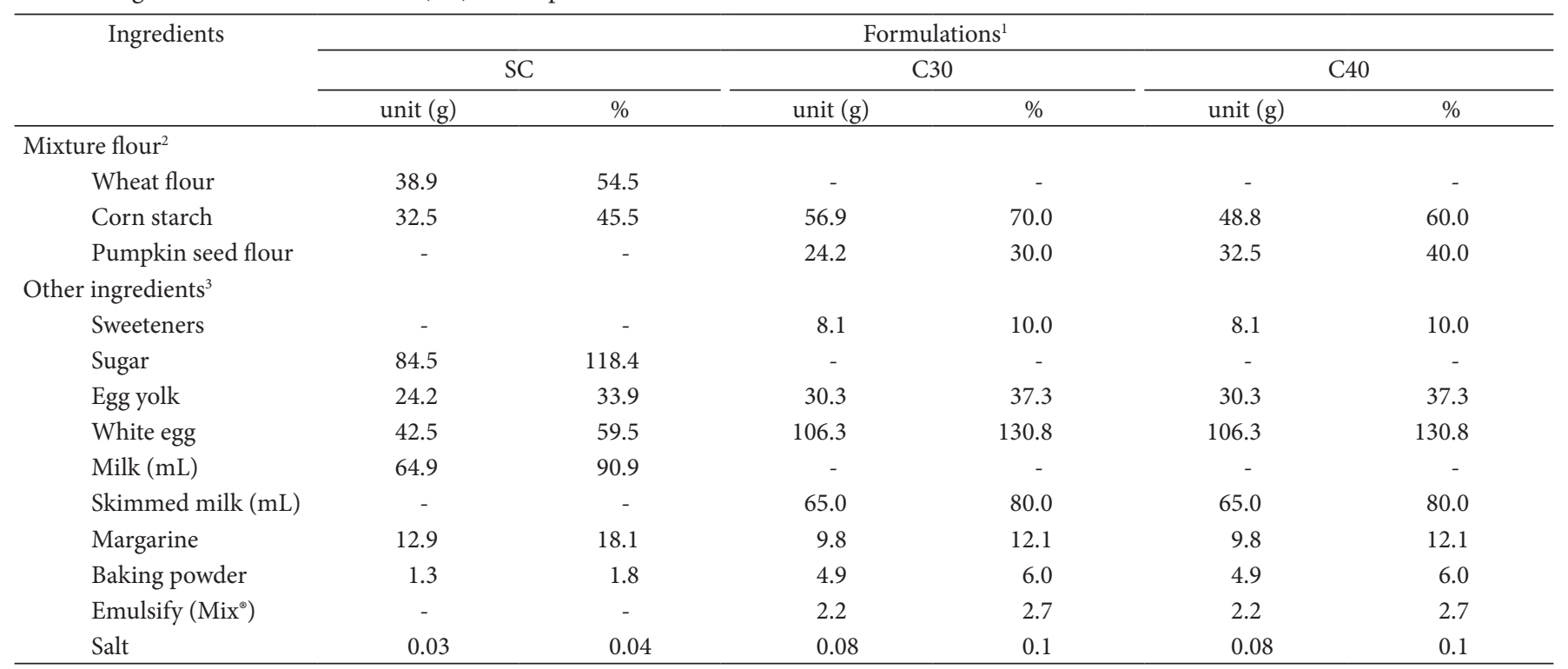

${ }^{1}$ Quantitaty and percentage in relation of total ingredients of cooking cake english type of $250 \mathrm{~g}$; ${ }^{2}$ percentage for mixture flour in relation of total weight flour in formulation; and ${ }^{3}$ percentage of ingredients in relation of weight flour mixture. 
case of C30 and C40, were homogenized using a mixer (Arno) for 2 minutes on medium speed.

Next, the emulsifier, flour blend, and milk were added, separated from each other, every 2 minutes on low speed. The yeast powder was also added to the batter on low speed. The whipped egg white, added with salt, was manually and smoothly mixed into the batter. The industrial oven was pre-heated for 10 minutes to each specific baking temperature. The batter was then spread on an aluminum tray lined with butter paper and taken to the oven for 20 minutes at $180^{\circ} \mathrm{C}$, in the case of SC. The batter of the experimental cakes $\mathrm{C} 30$ and C40 were prepared in the same way at $150{ }^{\circ} \mathrm{C}$ for 30 and 28 minutes, respectively. After baking, the oven was turned off and the batter was allowed to cool to room temperature, for all experimental cakes. The different baking conditions to which the C30 and C40 cake and the SC were submitted were based on the better conditions found for the experimental cakes, previously established, since the experimental cakes exhibited different behavior from that of the SC during baking.

\section{Macroscopic characterization of the cakes}

The morphological characteristics of the inside and crust of the SC, C30 and C40 cakes were obtained from a digital image recorded for further aspect evaluation. The images were taken using a 6.0 Mega Pixel Sony camera.

\section{Physical parameters}

Yield

The total yield of the cakes was determined according to AACC (AMERICAN..., 1995). The data were obtained through the mean of five samples using Equation 1:

Total yield $(\%)=\frac{\text { After baking weight }(g) \times 100}{\text { Pre }- \text { baking weight }(g)}$

Pre-baking conditions

The baked cakes were measured with a $30 \mathrm{~cm}$ ruler to determine length, width, and maximum and minimum height (Figure 2). In order to determine height, the maximum and minimum mean of the height was considered. The medium height, length, and width parameters were multiplied to obtain the dimension of the cakes. The data were obtained through the mean of the five samples.

Specific volume

The specific volume $\left(\mathrm{cm}^{3} \cdot \mathrm{g}^{-1}\right)$ was determined using the millet seed moving method (SILVA; BORGES; MARTINS, 2001; PEREZ, 2002; MOSCATTO; PRUDÊNCIO-FERREIRA; HAULY, 2004; ZAMBRANO et al., 2005). After the cakes were removed from the oven and cooled to room temperature, they were weighed in an analytical balance. The weighing $(\mathrm{g})$ procedures were done in triplicate for the SC, C30, and C40 cakes. In a beaker containing millet seeds, the volume of the cakes was determined (Figure 3), as shown by Equation 2:

Specific volume $\left(\mathrm{cm}^{3}\right)=\frac{\text { Volume of } 3 \text { cakes }\left(\mathrm{cm}^{3}\right)}{\text { Weight of } 3 \text { cakes }(\mathrm{g})}$

Raw batter density

The raw batter was transferred into a $1 \mathrm{~L}$ graduate cylinder, previously recalibrated, and the quantity of mass that occupies one unit of volume in the graduated cylinder $(\mathrm{mL})$ and the weight of the batter $(\mathrm{g})$ were measured in a digital balance. The weight and volume of the raw batter were related (ZAMBRANO et al., 2005; BORGES et al., 2006) as shown in Equation 3:

Raw batter density $\left(g \cdot m L^{-1}\right)=\frac{\text { Raw batter weight }(g)}{\text { Raw batter volume }(m L)}$

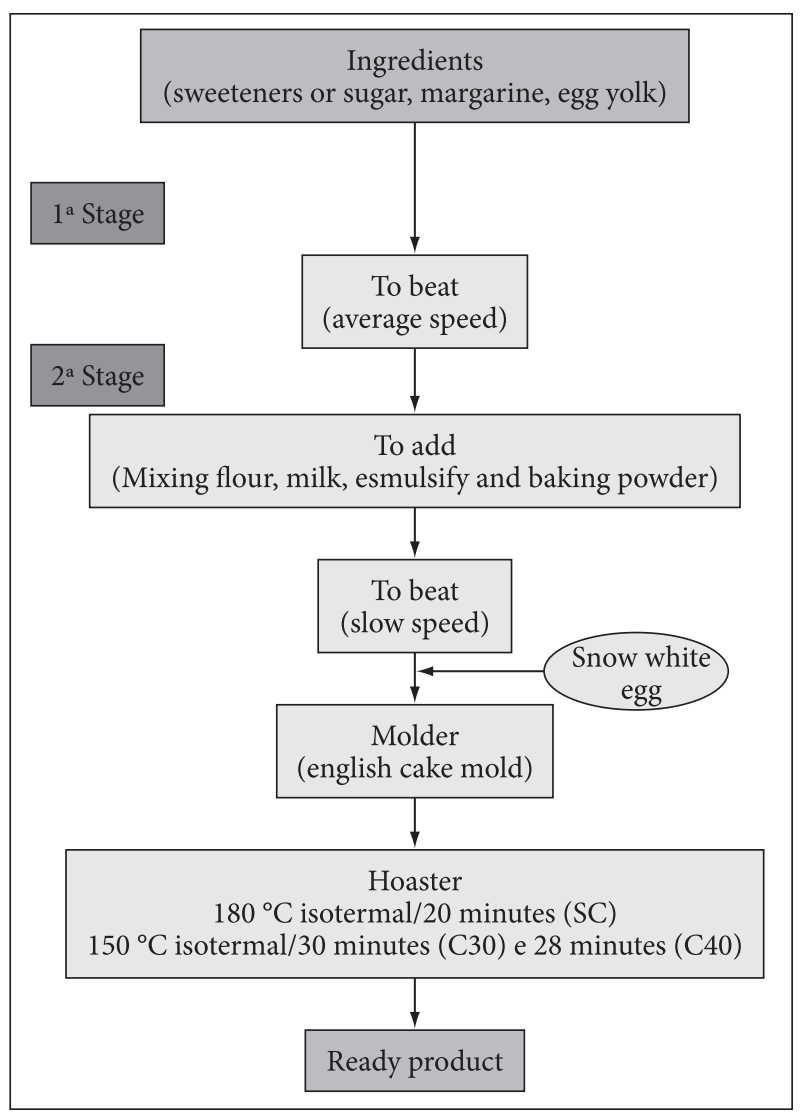

Figure 1. Diagram of standard cake (SC) and experimental cakes (C30 and C40) formulations.

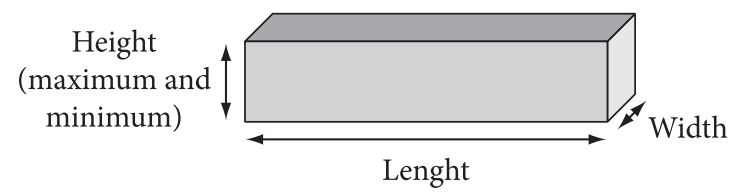

Figure 2. Roasted cake measurement. 

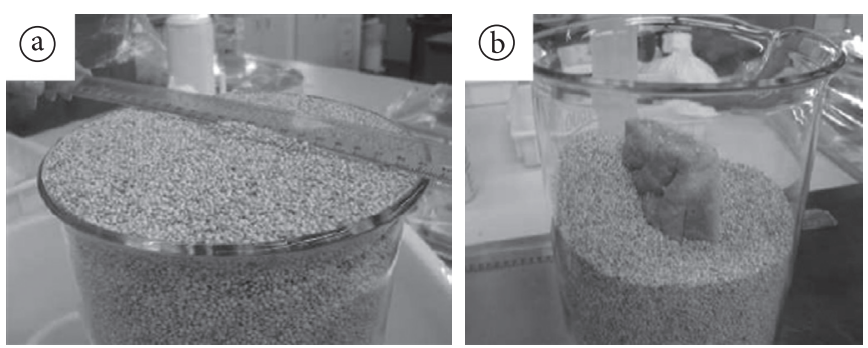

Figure 3. a) Leveling of pearl millet seeds in becher; and b) measurement of cake in central and vertical with after filling and leveling of pearl millet.

\section{Chemical composition of the formulations}

The chemical compositions of the SC, C30 (30\%), and C40 (40\%) cakes were determined as described by IAL (INSTITUTO..., 2005) in triplicate. In order to determine the moisture content, the samples were kept in the FANEM 215SE oven, at $105^{\circ} \mathrm{C}$, until a constant weight was reached. The ashes content was obtained by incineration in a Lavoisier oven.

In order to determine the lipids, the methodology 032 was applied by Soxhlet extraction; the methodology 037 was applied to determine proteins, and the classical Kjeldahl methodology was applied to determine the gross protein content by converting the nitrogen into factor 6.25 (INSTITUTO..., 2005).

The dietary fiber (DF) value was obtained from the literature on soluble fibers according to data found by Santangelo (2006). The soluble dietary fiber was also obtained from the literature (MENDEZ et al., 2001). The carbohydrates or nifext fraction were obtained by difference after the calculations of the fractions above. In order to determine the total caloric heat, factor 4 was applied for the proteins and carbohydrates and factor 9 for the lipids, according to the Atwater system (SOUTHGATE, 1981).

\section{Physicochemical characterization}

The $\mathrm{pH}$ values of the $\mathrm{SC}, \mathrm{C} 30$, and $\mathrm{C} 40$ cakes were determined according to IAL (INSTITUTO..., 1995) using $10 \mathrm{~g}$ of the sample cake, previously ground, added with $100 \mathrm{~mL}$ of distilled water, and agitated for 30 minutes and left undisturbed for 10 minutes. The $\mathrm{pH}$ was determined using a Procyon PHD-10 potenciometer.

The Total Titulable Acidity of the SC, C30, and C40 cake samples was determined from $2 \mathrm{~g}$ of flour in sodium hydroxide $(0,1 \mathrm{~N})$ using phenolphetalein as the indicator (INSTITUTO..., 1995).

The Total Soluble Solids (TSS) of the SC, C30, and C40 cakes were determined by adding $100 \mathrm{~mL}$ of distilled water into $10 \mathrm{~g}$ of cake, previously ground, agitated for 30 minutes and left undisturbed for 10 minutes. The TSS was determined by optical refractometry, and thus the refraction index determined the soluble solids and sugars present. The refractometer reading was corrected according to the room temperature during the analysis (IAL, 1995).
The analyses of $\mathrm{pH}$, Total Titulable Acidity (TTA), and TSS by refractometry were performed in triplicate.

The relationship between TSS and TTA was established by triplicates for the cakes using the results obtained through the ratio between themselves (MATSUURA et al., 2001; WUTKE et al., 2004).

The gluten content was determined in triplicate for the flours according to the IAL (INSTITUTO..., 1995) methodology. Therfore, the gluten content in the SC was determined by mathematical calculation from the results obtained with the SC blend flour. Similarly, since the cornstarch and PSF are glutenfree, there was no need to determine the presence of gluten in the $\mathrm{C} 30$ and $\mathrm{C} 40$ experimental cakes since the other ingredients used in the cakes, except for the SC, were also gluten free.

The Standard cake (SC) and experimental cakes (C30 and C40) baked and cooled were sliced as homogeneous as possible. Next, the analyses of moisture of the central part and external ring were performed, both in triplicate, using the oven method at $105{ }^{\circ} \mathrm{C}$ (INSTITUTO..., 1995). The moisture gradient was determined by the difference between the mean moisture values between the two parts evaluated.

\section{Statistical analysis}

The statistical analyses were performed using the Statistica software for windows, version 4.0, Statsoft, Inc, (1993). The physicochemical data of the C30 and C40 cakes were analyzed using analysis of variance (ANOVA) and the Tukey Test in order to compare the means at $5 \%$ level of significance.

\section{Results and discussion}

The centesimal composition of the PSF obtained was $5.12 \%$ of moisture, $3.69 \%$ of ashes, $36.12 \%$ of lipids, $33.65 \%$ of proteins, $29.50 \%$ of insoluble dietary fiber, and traces of carbohydrates. The caloric content was $461.56 \mathrm{kcal} .100 \mathrm{~g} \mathrm{~g}^{-1}$ of flour. A commercial cornstarch product was added to the PSF flour in the experimental cake mixes used.

\subsection{Macroscopic characterization of the cakes}

Figure 4 shows a commercial cake and the cakes prepared, SC, C30, and C40 sliced transversally, and it can be seen that C40 grew more homogeneously that C30.

The distribution of aeration in the $\mathrm{C} 40$ cake was more uniform than that of $\mathrm{C} 30$. The inside of the $\mathrm{C} 30$ and $\mathrm{C} 40$ cakes were more yellowish compared to that of the $\mathrm{SC}$, which is similar to the color of commercial whole bakery products. The coloration of the crust was shiny golden brown in the C30 and C40 cakes, whereas it was pale golden brown in the SC cake. The baked batter of the C30 and C40 cakes was firmer that of a commercial sugarless and fiberless cake that crumbled when sliced.

\subsection{Physical parameters}

There was no significant difference between the yields of the $\mathrm{C} 30$ and $\mathrm{C} 40$ experimental cakes ( $p>0.05$ ), but it was lower when compared to the SC $(\mathrm{p}<0.05)$. These results indicate that 
when the flour blend (FB) was added, the liquid evaporation was reduced during baking are shown in Table 2. Perez (2002) found the same results in a study with biscuits based on wheat and eggplant flour (EF), for which the result was: the higher the content of fiber in the flour, the lower the moisture loss.

There was no significant difference in the dimension and specific volume of the SC, C30, and C40 cakes. There was an increase in the dimension in relation to the raw batter after baking of 22.9, 22.8, and 21.2\% for the SC, C30, and C40 cakes, respectively. The decrease in the dimensions of $\mathrm{C} 30$ and $\mathrm{C} 40$ cakes is probably due to the fiber increase in the product.

Studying the specific volume of cakes made from WF and yacon flour and WF and yacon and inulin flour, Moscatto, Prudêncio-Ferreira and Hauly (2004) found that although the specific volumes of the experimental cakes were higher, they did not present significant difference when compared to the SC.

The value of density obtained was lower in the two experimental cakes, C30 (0.81 g.mL $\left.\mathrm{mL}^{-1}\right)$ and C40 (0.77 g.mL $\left.{ }^{-1}\right)$ indicating more possibility of aeration for the raw batter. On the other hand, the C30 and C40 specific volumes (1.89) and (1.94) were lower than those found by Marangoni (2007) with yacon flour and linseed. There was no significant difference between the density values of C30 and C40 cakes compared to that of the SC.

According to Borges et al. (2006), density is a measurement of incorporation and retention of air into the batter of the cake.
A lower value of density means higher incorporation of air, and higher values of density affect the volume of the product by resulting in a closer, more compact, and undesirable inside. By adding $45 \%$ of oatmeal to a wheat flour cake, the authors found that the aspect of the cakes was affected. According to Pavanelli, Cichello and Palma (2005), cakes such as sponge cake presented very low density values $(0.35$ and 0.45$)$ and the "neutral" cakes (ordinary cake) were denser $(0.70$ and 0.85$)$. The density values found for the C30 and C40 experimental cakes is within the "neutral" range.

\subsection{Chemical composition of the formulations}

The chemical composition of the SC, C30, and C40 cakes are shown in Table 3. The C30 and C40 cakes presented higher moisture values than that of the SC. The moisture content of the $\mathrm{C} 30$ and $\mathrm{C} 40$ cakes was 66.3 and $66.4 \%$ higher than that of the SC, respectively. The C40 moisture content was $1 \%$ higher than that of the $\mathrm{C} 30$. The higher percentage of the experimental cakes indicates a hygroscopic influence of the fibers. Oliveira and Reyes (1990), found that the biscuits made from corn fiber residue (23.2\% of fiber) presented more water retention and therefore reduced moisture loss. Similar results were found in the present work.

In the thermogravimetric analysis (TGA), the raw batter of $\mathrm{C} 30$ and C40 cakes presented higher contents of moisture than that of the SC. The raw batter of the C30 and C40 cakes was 29.50 and 55\%, respectively, during the water decomposition

Table 2. Physical parameters of standard cake (SC) and experimentals cakes (C30 and C40).

\begin{tabular}{|c|c|c|c|c|c|c|}
\hline \multirow[t]{2}{*}{ Physical parameters } & \multicolumn{2}{|c|}{ SC } & \multicolumn{2}{|c|}{ C30 } & \multicolumn{2}{|c|}{$\mathrm{C} 40$} \\
\hline & $\%$ & $\mathrm{SD}$ & $\%$ & $\mathrm{SD}$ & $\%$ & SD \\
\hline Total yield ${ }^{1}$ & $87.63^{\mathrm{a}}$ & \pm 1.07 & $84.79^{b}$ & \pm 0.16 & $85.17^{\mathrm{a}}$ & \pm 0.55 \\
\hline Dimensions after baking ${ }^{2}\left(\mathrm{~cm}^{3}\right)$ & $496.3^{\mathrm{a}}$ & \pm 48.2 & $540.0^{\mathrm{a}}$ & \pm 36.9 & $492.3^{\mathrm{a}}$ & \pm 44.2 \\
\hline Specific volume ${ }^{2}\left(\mathrm{~cm}^{3}\right)$ & $1.92^{\mathrm{a}}$ & \pm 0.25 & $1.89^{\mathrm{a}}$ & \pm 0.08 & $1.94^{\mathrm{a}}$ & \pm 0.16 \\
\hline Crude mass density ${ }^{2}\left(\mathrm{~g} \cdot \mathrm{mL}^{-1}\right)$ & $0.79^{\mathrm{a}}$ & \pm 0.007 & $0.81^{\mathrm{a}}$ & \pm 0.05 & $0.77^{\mathrm{a}}$ & \pm 0.02 \\
\hline
\end{tabular}

Avarages with the same letters, in the same line, not have difference between itself at Tukey test ( $\mathrm{p} \geq 0$,05); SC - Standard Cake, C30 - Cake with $30 \%$ of PSF, C40 - Cake with $40 \%$ of PSF; SD - Standard Deviation; ND - Not Determined; Fiber estimate: insoluble fiber C30 and C40 had to reference Santangelo (2006), and soluble and insoluble fiber of SC had to reference Mendez et al., (2001); ${ }^{1}$ Average of five repetitions; ${ }^{2}$ Avarage of three repetitions.

Table 3. Centesimal composition of standard cake (SC) and experimentals cakes.

\begin{tabular}{|c|c|c|c|c|c|c|c|}
\hline \multicolumn{2}{|c|}{ Determinations $^{1}$} & \multicolumn{2}{|c|}{ SC } & \multicolumn{2}{|c|}{$\mathrm{C} 30$} & \multicolumn{2}{|c|}{$\mathrm{C} 40$} \\
\hline & & $\%$ & SD & $\%$ & SD & $\%$ & $\mathrm{SD}$ \\
\hline Humidity & & $30.26^{\mathrm{b}}$ & \pm 0.69 & $50.33^{\mathrm{a}}$ & \pm 0.78 & $50.23^{\mathrm{a}}$ & \pm 2.37 \\
\hline Ashes & & $0.81^{\mathrm{b}}$ & \pm 0.09 & $1.81^{\mathrm{a}}$ & \pm 0.09 & $1.79^{\mathrm{a}}$ & \pm 0.27 \\
\hline Lipids & & $6.50^{c}$ & \pm 0.09 & $8.96^{\mathrm{b}}$ & \pm 0.21 & $10.74^{\mathrm{a}}$ & \pm 0.11 \\
\hline Proteins & & $5.71^{\mathrm{c}}$ & \pm 0.14 & $10.38^{\mathrm{b}}$ & \pm 0.08 & $12.28^{\mathrm{a}}$ & \pm 0.18 \\
\hline Alimentary Fiber & Total & $4.15^{\mathrm{a}}$ & - & \multicolumn{2}{|c|}{ ND } & \multicolumn{2}{|c|}{ ND } \\
\hline Carbohydrates $^{2}$ & & $52.57^{\mathrm{a}}$ & - & $20.62^{\mathrm{b}}$ & - & $14.63^{c}$ & - \\
\hline Calories $^{3}$ (Kcal) & & $291.62^{\mathrm{a}}$ & - & $204.64^{\mathrm{b}}$ & - & $204.30^{c}$ & - \\
\hline
\end{tabular}

Avarages with the same letters, in the same line, not have difference between itself at Tukey test ( $\mathrm{p} \geq 0,05)$; SC - Standard Cake, C30 - Cake with $30 \%$ of PSF, C40 - Cake with $40 \%$ of PSF; SD - Standard Deviation; ND - Not Determined; Fiber estimate: insoluble fiber C30 and C40 had to reference Santangelo (2006), and soluble and insoluble fiber of SC had to reference




process and 34.42 and 58\% when baked, respectively (SILVA, 2007). The results obtained in the TGA analysis and those of oven dehydration were close.

There was no significant difference between the ash content of the C30 and C40 experimental cakes, but a significant difference was found between these values and that of the SC. This is due to the higher content of minerals present in the C30 and C40 cakes, especially the iron content in the PSF (FRANCO, 2002).

The lipid content of the cakes increased with the addition of PSF to the flour blend. The lipid content of the C30 and C40 cakes was 37.85 and $65.32 \%$ higher than that of the SC, respectively, and the $\mathrm{C} 40$ cake presented $19.87 \%$ more lipids than the $\mathrm{C} 30$ cake.

The protein content was statistically different for all cakes. The protein content of the $\mathrm{C} 30$ and $\mathrm{C} 40$ cakes was 81.79 and $115.06 \%$ higher than that of the SC, respectively. The C40 cake presented $18.30 \%$ more protein than the C30 cake. It can be said that the addition of PSF contributed to the increase in the protein content of the experimental cakes.
In the thermogravimetric analysis (TA/TGA), the whole PSF and the BF 40 added to the cakes showed protein presence at $220^{\circ} \mathrm{C}$. Nonetheless, the raw and baked batter of the $\mathrm{C} 30$ and C40 cakes did not show protein decomposition but the SC cake did (SILVA, 2007). In 2007, Silveira studied the decomposition of biscuits made from flour blend pumpkin seed. Through the analysis of TA/TGA, the author found 14\% of decomposition of the material in terms of protein at $222^{\circ} \mathrm{C}$. Through oven analysis, the author found $6.41 \%$ of protein.

In the present work, the presence of protein was confirmed using the IAL (INSTITUTO..., 2005) methodology; nevertheless it was not confirmed by thermal analysis. Therefore, further investigation is needed.

The fiber content of the C30 and C40 cakes was higher than that of the SC even when comparing the insoluble fiber content of C30 (7.9\%) and C40 (10.2\%) with the total fiber content of the SC (41.5\%). With the addition of PSF to the flour blends, the insoluble fiber content increased in the cakes. The C40 presented $29.11 \%$ more fiber content than the C30 and $145.78 \%$ more than the SC, and the insoluble fiber content of the C30 cake was $90.36 \%$ higher than that of the SC.
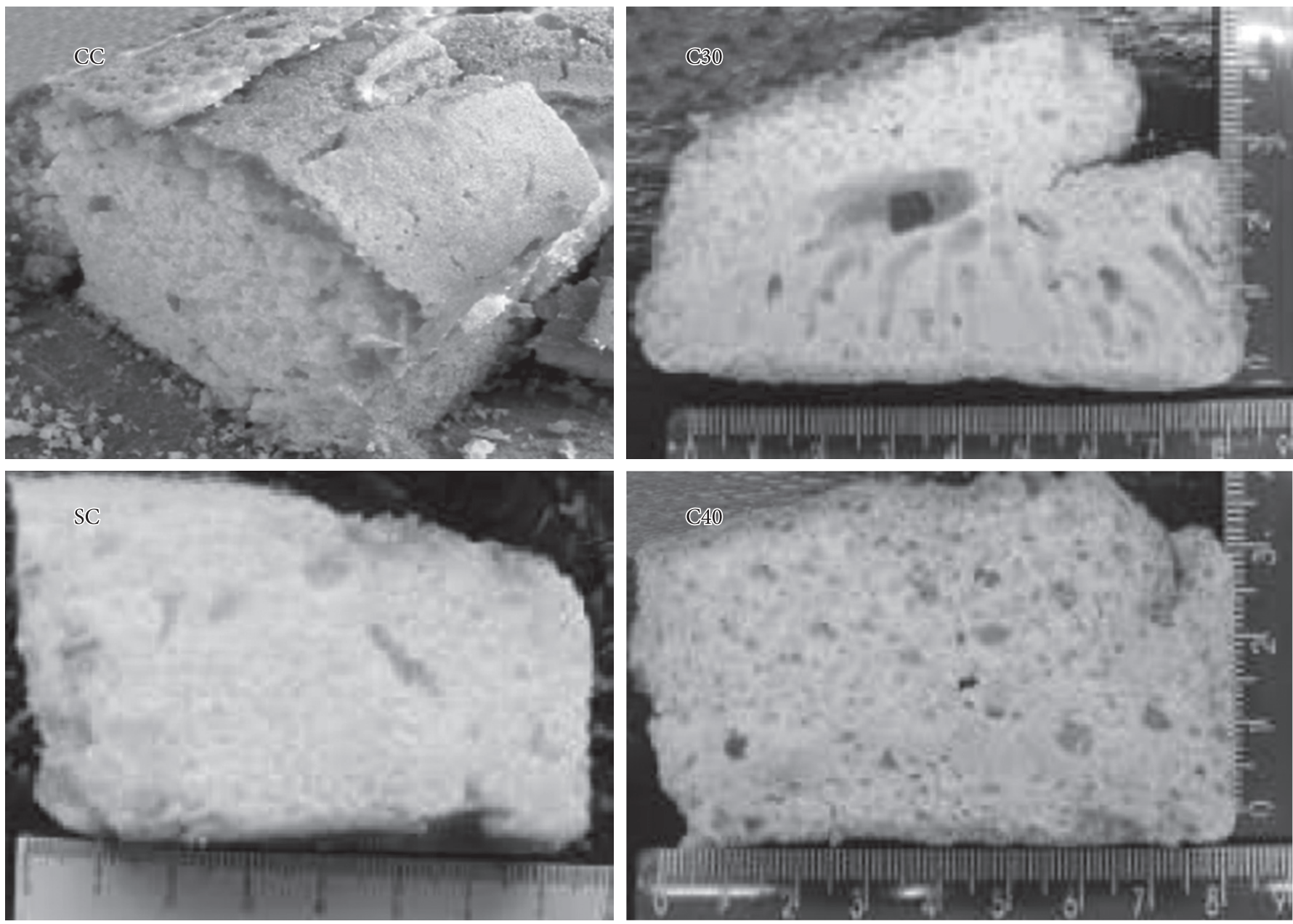

Figure 4. Transversal cut of Commercial (CC), SC, C30 and C40 cakes. 
According to Silva, Borges and Martins (2001), the addition of two different Jatobá flours increased the content of ashes and total dietary fibers. Similar results were found by using PSF in the present work. The content of carbohydrates was statistically different among the cakes evaluated. The C30 and C40 cakes presented, respectively, 60.78 and $72.1 \%$ less carbohydrates than the SC. The C40 cake presented $29.05 \%$ less carbohydrates than the C30. The caloric content of the C30 and C40 cakes was 29.83 and $29.94 \%$ lower than that of the SC, respectively. The higher calorie content of the SC is related to the presence of carbohydrates. The calorie content of the $\mathrm{C} 40$ is slightly higher than that of the C30 (0.17\%) due to the lower content of carbohydrates and higher fiber content although it has higher lipid and protein content than that of C30.

Moscatto, Prudêncio-Ferreira and Hauly (2004), verified that the addition of inulin flour to wheat flour decreased significantly the calorie content. Zambrano et al. (2005) managed to reduce the calorie content of cakes by replacing fats with gums. In the present work, the flour blend with PSF, which was added to the C30 and C40 cakes, also decreased the calorie content compared to that of the SC. However, such decrease was primarily due to the presence of dietary fibers.

Final solid products, such as cakes, should have at least $3 \mathrm{~g}$ of fiber in order to be considered a source of fiber and at least $6 \mathrm{~g}$ of fiber. $100 \mathrm{~g} \mathrm{~g}^{-1}$ to be considered a rich source of dietary fiber (BRASIL, 1998). The C30 and C40 cakes are therefore considered products rich in dietary fiber although only the insoluble fiber content is considered.

\subsection{Physicochemical characteristics}

The results of the analysis of $\mathrm{pH}$, Total Titulable Acidity (TTA), and Total Soluble Solids (TSS), of the gluten content and the moisture gradient in the SC and the C30 and C40 experimental cakes are shown in Table 4.

It can be seen that the $\mathrm{pH}$ of the $\mathrm{C} 30$ and $\mathrm{C} 40$ cakes presented significant differences in relation to the SC, but not between each other. All cakes presented close to neutral $\mathrm{pH}$ values.

The Total Titulable Acidity (TTA) presented no significant difference between C30 and C40 but presented significant difference between SC and C40. It can be seen that the acidity of the cakes increased with the addition of PSF, probably due to the presence of fatty acids. There is no minimum acidity limit value established for cakes according to legislation.

The C30 and C40 cakes presented significant statistical differences in terms of TSS. It is worth noting that the C30 and C40 experimental cakes have less content of soluble solids than that of the SC, characteristic attested by the addition of the blend flours used.

The TSS/TTA ratio presented significant difference for all cakes. The SC presented a higher ratio than that of the experimental cakes. The $\mathrm{C} 40$ cake presented a $3.4 \%$ higher ratio than that of the $\mathrm{C} 30$ cake. The $\mathrm{C} 30$ cake ratio was way lower than that of the $\mathrm{C} 40$ cake due to their lower content of carbohydrates and also due to the higher content of good quality fatty acids. Only the SC has gluten. The experimental cakes are made from gluten-free ingredients.

The moisture gradient characterizes the difference between the moisture of the inside and crust of the baked products. There was a significant difference for all cakes evaluated. The C30 cake gradient was $67.07 \%$, and the C40 was $68.81 \%$ higher than the SC cake.

The C40 cake moisture gradient was $1.04 \%$ higher than that of the C30 cake. Such difference between the SC and the C30 and C40 experimental cakes can be explained by the higher water retention of products enriched with fiber. Hence, the C40 moisture gradient was higher since it has higher fiber content that of the other cakes evaluated. The C30 and C40 cakes presented higher water retention, and a greater difference between the moisture content in the crust and in the inside of the cake was observed due to the external layer evaporation. The presence of dietary fiber confirmed the hygroscopic power in the C30 and C40 cakes. The SC presented a way lower moisture gradient than that of the $\mathrm{C} 30$ and $\mathrm{C} 40$ cakes.

Santangelo (2006) verified that the moisture gradient of panetone (a sweet bread loaf originally usually prepared and enjoyed for Christmas) with $30 \%$ of PSF was lower than that of the control panetone, 5.91 and $0.44 \%$ respectively. This characteristic is due to the higher fiber content in the panetone with PSF.

Table 4. Physiochemical determination of cakes.

\begin{tabular}{|c|c|c|c|c|c|c|}
\hline \multirow[t]{2}{*}{ Determinations $^{1}$} & \multicolumn{2}{|c|}{ SC } & \multicolumn{2}{|c|}{ C30 } & \multicolumn{2}{|c|}{$\mathrm{C} 40$} \\
\hline & $\%$ & SD & $\%$ & SD & $\%$ & $\mathrm{SD}$ \\
\hline $\mathrm{pH}$ & $6.79^{\mathrm{b}}$ & \pm 0.19 & $7.74^{\mathrm{a}}$ & \pm 0.04 & $7.47^{\mathrm{a}}$ & \pm 0.09 \\
\hline TA (\% mL/g) & $0.36^{\mathrm{b}}$ & \pm 0.06 & $0.54^{\mathrm{ab}}$ & \pm 0.01 & $0.63^{\mathrm{a}}$ & \pm 0.15 \\
\hline SST (\%) & $3.98^{\mathrm{a}}$ & \pm 0.17 & $1.61^{\mathrm{b}}$ & \pm 0.25 & $1.94^{\mathrm{b}}$ & \pm 0.14 \\
\hline Relation SST/TA & $11.05^{\mathrm{a}}$ & - & $2.98^{\mathrm{c}}$ & - & $3.08^{\mathrm{b}}$ & - \\
\hline Gluten (\%) & $4.62^{\mathrm{a}}$ & \pm 0.69 & $0.00^{\mathrm{b}}$ & - & $0.00^{\mathrm{b}}$ & - \\
\hline
\end{tabular}

Avarages with the same letters, in the same line, not have difference between itself at Tukey test ( $\mathrm{p} \geq 0,05)$; SC - Standard Cake, C30 - Cake with $30 \%$ of PSF, C40 - Cake with $40 \%$ of PSF; SD - Standard Deviation; ${ }^{1}$ average of three repetitions, in \% drought base. 


\section{Conclusions}

Base on the findings, it can be concluded that flour blends with PSF and cornstarch proved adequate ingredients for the preparation of the experimental cakes since both the macroscopic and chemical characteristics showed satisfactory results. The cakes presented higher soluble fiber content and less calorie content than those of the Standard Cake. The C40 cake presented the best macroscopic and physical results compared to those of the C30 cake.

The experimental cake formulations proved technological viability and offered a novel product to the market of gluten-free, diet products enriched with dietary fiber and low in calories, which is beneficial to human health, especially in special diets reaching a broad age range.

\section{Acknowledgements}

The authors are grateful for the financial support provided by CAPES (Brazilian research supporting foundation).

\section{References}

AMERICAN ASSOCIATION OF CEREAL CHEMISTS - AACC. Approved methods of the AACC. $8^{\text {th }}$ ed. Saint Paul: 1995. v. 1-2.

ANJUM, F. M. et al. Wheat gluten: high molecular weight glutenin subunits - structure, genetics, and relation to dough elasticity. Journal of Food Science, v. 72, n. 3, p. 56-63, 2007.

BERETTA, D. Caracterização físico-química de farinha à base de semente de abóbora, Cucurbita maxima, L., e aplicação na indústria alimentícia. 2007. $171 \mathrm{f}$. Dissertação (Mestrado em Tecnologia de Processos Químicos e Bioquímicos) - Centro de Tecnologia, Escola de Química, Universidade Federal do Rio de Janeiro, Rio de Janeiro, 2007.

BERETTA, D. et al. Caracterização de farinha integral e de farinhas mistas sem glúten à base de semente de abóbora (Cucurbita maxima, L.). In: SIMPÓSIO LATINO AMERICANO DE CIÊNCIA DE ALIMENTOS, 7., 2007, Campinas. Anais... Campinas: Editora da UNICAMP, 2007.

BORGES, J. T. S. et al. Utilização de farinha mista de aveia e trigo na elaboração de bolos. Boletim Ceppa, v. 24, n. 1, p. 145-162, 2006.

BRASIL. Ministério da Saúde. Agência Nacional de Vigilância Sanitária. Portaria $n^{\circ}$ 27, de 13 de janeiro de 1998. Regulamento Técnico referente à Informação Nutricional Complementar, declarações relacionadas ao conteúdo de nutrientes. Brasília: Ministério da Saúde, 1998. 11 p. Disponível em: <http://www.anvisa.gov.br>. Acesso em: 23 abr. 2007.

BRASIL. Ministério da Saúde. Agência Nacional de Vigilância Sanitária. Resolução RDC n 360, de 23 de dezembro de 2003. Regulamento Técnico sobre Rotulagem Nutricional de Alimentos Embalados, tornando obrigatória a rotulagem nutricional. Brasília: Ministério da Saúde, 2003. 12 p.

BRASIL. Ministério da Saúde. Secretaria de Atenção à Saúde. Coordenação-geral da Política de Alimentação e Nutrição. Guia alimentar para a população brasileira: promovendo a alimentação saudável. Brasília: Ministério da Saúde, 2005. 236 p.

CAFÉ, S. L. et al. Cadeia produtiva do trigo. BNDES Setorial, n. 18, p. 193-220, 2003. Disponível em: <http://www.bndes.gov.br/ conhecimento/bnset/set1806.pdf>. Acesso em: 9 ago. 2007.
CAMPOS, V. M. C. Dossiê técnico: produção de doces diet para diabéticos. Fundação Centro Tecnológico de Minas Gerais, 2007. Disponível em: <http://www.sbrt.ibict.br>. Acesso em: 30 jul. 2007. $25 \mathrm{p}$.

CARDELlO, H. M. A. B.; DAMÁSIO, M. H. Edulcorantes e suas características: Revisão. Boletim SBTCA, v. 31, n. 2, p. 241-248, 1997.

CARESTIATO, T. et al. Caracterização e processamento de farinha de semente de abóbora baiana (Cucurbita moschata). In: SIMPÓSIO LATINO AMERICANO DE CIÊNCIA DE ALIMENTOS, 6., 2005, Campinas. Anais... Campinas: Editora da UNICAMP, 2005.

CERQUEIRA, P. M. Aplicação da farinha de semente de abóbora (Curcurbita maxima, L.) no trato intestinal e no metabolismo glicídico e lipídico em ratos. 2006. 68 f. Dissertação (Mestrado em Ciência e Tecnologia de Alimentos)-Instituto de Tecnologia, Universidade Federal Rural do Rio de Janeiro, Rio de Janeiro, Brasil, 2006.

DALLEMOLE-GIARETTA, R. et al. Efeito do extrato aquoso de sementes de abóbora sobre a eclosão e inativação de juvenis. Revista Trópica: Ciências Agrárias e Biológicas, v. 3, n. 1 p. 3-6, 2009.

DEL-VECHIO, G. et al. Efeito no tratamento térmico em sementes de abóboras (Curcubita spp.) sobre os níveis de fatores antinutricionais e/ou tóxicos. Ciência e Agrotecnologia, v. 29, n. 2, p. 369-376, 2005.

DIGA não ao desperdício. São Paulo: Secretaria de Agricultura e Abastecimento, 1992. $110 \mathrm{p}$.

DOURADO, M. T. et al. Resposta biológica - CEA (Coeficiente de Eficácia Alimentar) e consumo de proteínas em ratas alimentadas com rações ricas em fibras de aspargo. In: CONGRESSO BRASILEIRO DE CIÊNCIA E TECNOLOGIA DE ALIMENTOS, 17., 2000, Fortaleza. Anais... Fortaleza: UFCE, 2000.

EL-ADAWY, T. A; TAHA, K. M. Characteristics and composition of different seed oils and flours. Food Chemistry, v. 74, p. 47-54, $2001 \mathrm{~b}$.

EL-ADAWY, T. A; TAHA, K. M. Characteristics and composition of watermelon, pumpkin, and paprika seed oils and flours. Journal of Agricultural and Food Chemistry, v. 49, p. 1253-1259, $2001 \mathrm{a}$.

ESTEVES, C. L. M. et al. Estudo sobre a utilização integral dos alimentos. Rio de Janeiro: Secretária da Agricultura e Abastecimento, 1993. 257 p.

FERREIRA, A.; LANFER-MARQUEZ, U. M. Legislação brasileira referente à rotulagem nutricional de alimentos. Revista de Nutrição, v. 20, n. 1, p. 83-93, 2007.

FRANCO, G. Tabela de composição química dos alimentos. 9. ed. São Paulo: Atheneu, 2002.

FUNCK, L. G.; BERRERRA-ARELLANO, D.; BLOCK, J. M. Ácido linoléico conjugado (CLA) e sua relação com a doença cardiovascular e os fatores de risco associados. Arquivos Latino Americanos de Nutrição, v. 56, n. 2, 2006. Disponível em: <www. alanrevista.org/ediciones/2006-2/acido_linoléico_conjugado.asp $>$. Acesso em: 3 Oct. 2007.

GALVÃO, L. C. et al. Apresentação clínica de doença cilíaca em crianças durante dois períodos, em serviço universitário especializado. Arquivo de Gastroenterologia, v. 41, n. 4, p. 234-238, 2004.

HADJIVASSILOU, M. et al. Does cryptic gluten sensitivity play a part in neurological illness? The Lancet, v. 347, p. 369-371, 1996.

INSTITUTO ADOLFO LUTZ - IAL. Métodos químicos para análise em alimentos. 3. ed. Brasília,1995.

INSTITUTO ADOLFO LUTZ - IAL. Métodos químicos para análise em alimentos. 4. ed. Brasília, 2005. 
KALLUF, V. H. Desidratação da polpa de abóbora (Cucurbita moschata) e seus teores de beta-caroteno. 2006. 59 f. Dissertação (Mestrado em Tecnologia dos Alimentos)-Universidade Federal do Paraná, Paraná, Brasil.

MAHAN, L. K; ESCOTT-STUMP, S. Krause alimentos, nutrição e dietoterapia. 10. ed. São Paulo: Roca, 2002.

MARANGONI, A. L. Potencialidade de aplicação de farinha de yacon (Polymnia sonchifolia) em produtos à base de cereais. 2007. $125 \mathrm{f}$. Dissertação (Mestrado em Tecnologia de Alimentos)-Faculdade de Engenharia de Alimentos, Universidade Estadual de Campinas, Campinas, 2007.

MATSUURA, F. C. A. K. U. et al. Avaliações físico-químicas em frutos de diferentes genótipos de acerola (Malpighia punicifolia L.). Revista Brasileira de Fruticultura, São Paulo, v. 23, n. 3, p. 602-606, 2001.

MENDEZ, M. H. M. et al. Tabela de composição de alimentos: amiláceos, cereais e derivados, frutas, hortaliças, leguminosas, nozes e oleaginosas. Niterói: EdUFF, 2001.

MOSCATTO, J. A.; PRUDÊNCIO-FERREIRA, S. H.; HAULY, M. C. $O$. Farinha de yacon e inulina como ingredientes na formulação de bolo de chocolate. Ciência e Tecnologia de Alimentos, v. 24, n. 4, p. 643-640, 2004.

MURKOVIC, M. et al. Changes in chemical composition of pumpkin seeds during the roasting process for production of pumpkin seed oil. Part 1: non-volatile compounds. Food Chemistry, v. 84, p. 359-365, 2004.

OLIVEIRA, S. P.; REYES, F. G. R. Biscoito com alto teor de fibra de milho: preparo, caracterização química e tecnológica e teste de aceitabilidade. Ciência e Tecnologia de Alimentos, v. 10, n. 2, p. 261-272, 1990.

ORNELLAS, L. H. Técnica dietética: seleção e preparação de alimentos. 7. ed. São Paulo: Atheneu, 2002.

PAVANELLI, A. P.; CICHELLO, M. S.; PALMA, E. J. Emulsificantes como agentes de aeração em bolos. Oxiteno, 2005. 10 p. Artigo técnico. Disponível em: <http://www.oxiteno.com.br/ aplicacoes/mercados/doc/documento.asp?artigotecnico $=1 \& \mathrm{~s}$ egmento=0100\&idioma $=P O \& r=. p d f>$. Acesso em: 5 out. 2006.

PEREIRA, E. D. et al. Produção e análise sensorial de cocada enriquecida com farinha de semente de abóbora (Curcubita moschata). In: SEMANA DE CIÊNCIA E TECNOLOGIA DO IFMG CAMPUS BAMBUÍ, 2.; JORNADA CIENTÍFICA, 2., 2009. Anais... Minas Gerais: Editora da UFMG, 2009.

PEREZ, P. M. P. Elaboração de biscoito tipo salgado, com alto teor de fibra alimentar, utilizando farinha de berinjela (Solanum melongena, L). 2002. 157 f. Dissertação (Mestrado em Ciência e Tecnologia de Alimentos)-Instituto de Tecnologia, Universidade Federal Rural do Rio de Janeiro, Rio de Janeiro, 2002.
POSSAMAI, T. N. Elaboração do pão de mel com fibra alimentar proveniente de diferentes grãos, sua caracterização físicoquímica, microbiológica e sensorial. 2005. 82 f. Dissertação (Mestrado em Tecnologia de Alimentos)-Universidade Federal do Paraná, Curitiba, 2005.

PUMAR, M. et al. Avaliação do efeito fisiológico da farinha de semente de abóbora (Cucurbita maxima, L.) no trato intestinal de ratos. Ciência e Tecnoloia de Alimentos, v. 28, supl., p. 7-13, 2008.

RAUEN, M. S.; BACK, J. C. V.; MOREIRA, E. A. M. Doença celíaca: sua relação com a saúde bucal. Revista de Nutrição, v. 18, n. 2, p. 272-276, 2005.

SANTANGELO, S. B. Utilização da farinha de semente de abóbora (Cucurbita maxima, L.) em panetone. 2006. 84 f. Dissertação (Mestrado em Ciência e Tecnologia de Alimentos)-Instituto de Tecnologia, Universidade Federal Rural do Rio de Janeiro, Rio de Janeiro, Brasil.

SDEPANIAN, V. L.; MORAIS, M. B.; FAGUNDES-NETO, U. Doença celíaca: a evolução dos conhecimentos desde sua centenária descrição original até os dias atuais. Arquivo de Gastroenterologia, v. 36, n. 4, p. 244-257, 1999.

SILVA, C. M. Farinha de semente de abóbora baiana: caracterização tecnológica e aplicação em produto de panificação. 2007. 195 f. Dissertação (Mestrado em Tecnologia de Processos Químicos e Bioquímicos)-Escola de Química, Centro de Tecnologia, Universidade Federal Rio de Janeiro, Rio de Janeiro, Brasil.

SILVA, M. R.; BORGES, B.; MARTINS, K. A. Avaliação química, física e sensorial de biscoitos enriquecidos com farinha de jatobádo-cerrado e de jatobá-da-mata como fonte de fibra alimentar. Brazilian Journal of Food Technology, v. 4, p. 163-170, 2001.

STATISTICA for windows. Versão 4.0. Statsoft, 1993.

STRINGHETA, P. C. et al. Políticas de saúde e alegações de propriedades funcionais e de saúde para alimentos no Brasil. Revista Brasileira de Ciências Farmacêuticas, v. 43, n. 2, p. 181-194, 2007.

TURANO, W. et al. Prevenção das hiperlipidemias e hiperglicemia pela ação do resíduo da laranja pêra. In: CONGRESSO BRASILEIRO DE CIÊNCIA E TECNOLOGIA DE ALIMENTOS, 17., 2000, Fortaleza. Anais... Fortaleza, 2000.

WUTKE, E. B. et al. Qualidade de frutos de videira 'Niagara rosada' em cultivo intercalar com gramínea e leguminosas. Revista Brasileira de Fruticultura, v. 26, n. 1, p. 92-96, 2004.

YOUNIS, C. Y. M. H.; GHIRMAYB, S.; AL-SHIHRYC, S. S. African Cucurbita pepo L.: properties of seed and variability in fatty acid composition of seed oil. Phytochemistry, v. 54, p. 71-75, 2000.

ZAMBRANO, F. et al. Efeito das gomas guar e xantana em bolos como substitutos de gordura. Brazilian Journal of Food Technology, v. 8, n. 1, p. 63-71, 2005. 